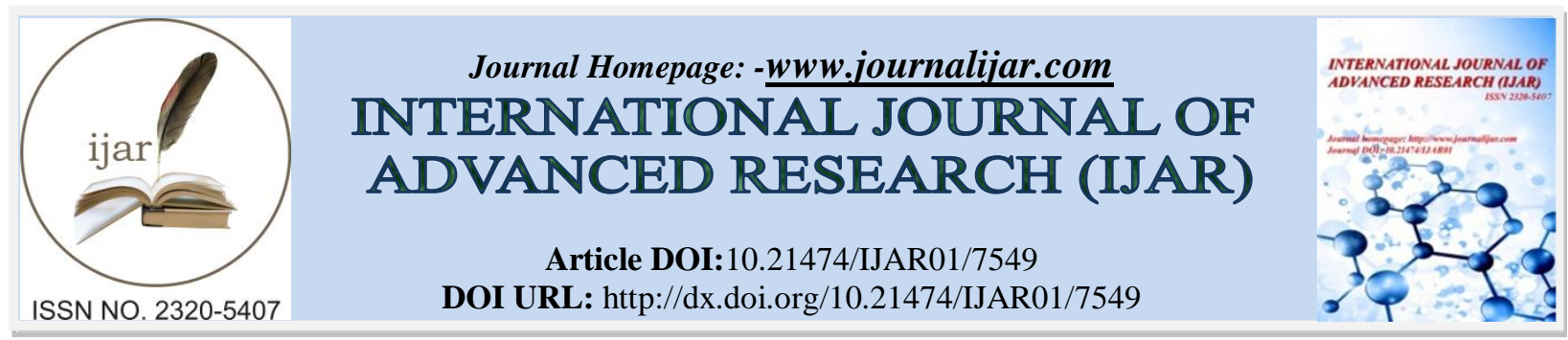

RESEARCH ARTICLE

\title{
FACTORS INFLUENCING GROWTH OF FISH PROCESSING FIRMS IN PUNTLAND: THE CASE OF BOSSASO DISTRICT.
}

Mr. Abdihakiim Abdullahi Nuh, Prof. Willy Muturi and Prof. Mohamed Said Samantar

Research project submitted to the department of development studies, in the school of communication and development studies, college of human resource development in partial fulfilment of the requirement for the award of the master degree at, jomokenyatta university of agriculture and technology. Jkuat.

\section{Manuscript Info}

Manuscript History

Received: 12 June 2018

Final Accepted: 14 July 2018

Published: August 2018

\section{Abstract}

Fish harvesting in Somalia is very limited and unexploited natural resource due to existence of several factors that influence the growth of the fishing processing firms. This study focused on the factors influence growth of the fishing processing firms in Puntland State of Somalia. The general objective of this study was to examine the factors influence growth of the fishing processing firms in Puntland. The study examined how variables such as technical skills availability, Capital availability and culture are influence growth of the fish processing firms. The study was quantitative in nature; the study targeted population of 96 respondents from fish companies' in the Bosasso districts of Bari region in Puntland. in Somalia Economics, whereas has been facing many problems including the serious challenges of widespread Illegal fishing for Somalia costal area, Piracy, the poor skill of Somali fishers and these are extensive factors which have main challenge caused of low growth of Puntland fishing sector. The general aim of this research is to evaluate and measure the factors influence on growth of fishing processing firm from Puntland urban areas. The research also was measure the impact between research variables and growth of fishing processing firms on general of Puntland State. In Methodology chapter, focuses on the manner in which the research problem was investigating by referring to the sampling method, selection of respondents, data gathering instrument(s) (e.g. questionnaire) and the statistical techniques that was utilizing. The findings of the study have been divided into three based variables, which was the factors influencing Growth on fish processing firms in Bosaso district Puntland of Somalia. For the purpose of the study, a review of the literature indicates that using the factors influencing growth on fish processing firms could be an effective indicator for understanding the magnitude of the problem and the possible areas for investigation to understand what the factors are influencing growth of the fish firms in Bosaso. The conclusions coming out from the findings of the research that sought to find out the factors influencing on growth of fish processing firms in Bosaso were summarized below based on the purpose of the study. The purpose of the study was to investigate factors influencing on growth of fish processing firms in Bosaso

Corresponding Author:-Abdihakiim Abdullahi Nuh.

Address:-Research project submitted to the department of development studies, in the school of communication and development studies, college of human resource development in partial fulfilment of the requirement for the award of the master degree at, jomokenyatta university of agriculture and technology. JKUAT and PSU. 
Puntland Somalia. These factors including the influence of Capital availability, and regarding on this, it has already been demonstrated in this study the most important challenge is the poor state of the investment in Puntland specifically and in Somalia in general. The second factor of study was technical skill availability and according to the study analyses, the main systemic challenge here is one of skills, knowledge and attitudes of the fisheries business community. There is a general lack of awareness of the market potential of marine and fisheries products, skills in fishing, handling catch, processing (cottage and industrial), business planning and marketing. Last variable of this study is Culture practices and as found the study, culture is one of the factors influence growth of fish firms, because, although fish is plentiful in the waters off the Somali coast, Somalis generally do not like to eat fish because of culture. In base of the findings of this study the researcher was recommending that, the Puntland Government to support construction of Cold rooms and fish processing centres. Also, recommended the Small firms can make together one corporation which can enable to cover financialcapacity required business fish companies. To enhancing the skill of the staff working with the fish firms, recommend to make staff capacity building as to upgrade their technical skills and knowledge and also, providing training to improving fish handling, Marketing and processing to stakeholder of fish market. Taking awareness and mobilization on adverse impact of fish consumption benefits and how can contribute the economic developments.

Copy Right, IJAR, 2018,. All rights reserved.

\section{Introduction:- \\ Background:-}

Fishing is one of the oldest economic occupations of mankind and is carried out for subsistence and commercial purposes. In developed countries it is highly commercialized while in developing countries it is mainly carried out for subsistence purposes. Fishing is carried out along all coastlines, in enclosed seas and in inland fresh waters. However, the main fishing grounds of the world are located in the cool waters of Pacific and Atlantic coasts within the temperate latitudes of northern hemisphere. Each account for $40 \%$ of the world's annual total fish hauls while Indian Ocean account for about $4 \%$. Aqua culture account for about 15\%. According to (Food and Agriculture Organisation, 2008) throughout the centuries fish has been an important component of the population's diet in many parts of the world. Fish catches increased rapidly over the past hundred years due to improved technology, which provided more powerful engines and sonar equipment. This led to over fishing and caused a worldwide decrease in wild stocks. As a result, the growth in fish catches stopped some 20 years ago. The need to increase fish production by farming became therefore an urgent matter. According to (FAO, 2007), top producers of aquaculture are China, India, Viet Nam, Indonesia and Thailand. China, with one-fifth of the world's population, accounts for two-thirds of the worlds reported aquaculture production. (China, 2005), was 32.4 million tonnes, more than 10 times that of the second ranked nation, India, which reported 2.8 million tonnes (FAO, 2009). Since 2002, China has been the world largest exporter of fish and fish products. In 2005, exports, including aquatic plants, were valued at US\$7.7 billion, with Japan, the United States and the Republic of Korea as the main markets. In 2005, the total number of fish farmers 33 world-wide.

was about 12 million with China reported 4.5 million people employed full time in aquaculture. In the past, fish culture in China has been a family business with traditional techniques passed from generation to generation. However, in the late 1960s the Chinese government began a move to the modern induced breeding technologies such that fish grow rapidly and has a high feed conversion rate, which has resulted in a rapid expansion of (Weimin, 2007). 
Aquaculture was introduced to Sub-Saharan Africa in the 1950s with main objectives of improved nutrition in rural areas, generation of additional income, diversification of activities to reduce risk of crop failures and the creation of employment in rural areas (Hecht, 2006). About $43 \%$ of the African continent is assessed as having the potential for farming tilapia, African catfish and carp (Ridler and Hishamunda, 2001). Though aquaculture has grown strongly in most regions of the world where the potential exists, it has not done Factors Affecting Profitability of Fish Farming Under Economic Stimulus Programme in Tigania, So, in Sub-Saharan Africa. In spite of various efforts since the 1950s, returns on government and international aquaculture investments appeared to be insignificant (FAO, 2004), with less than $5 \%$ of the suitable land area being used (Kapetsky, 2004).

(Hecht, 2006) is less than 1\%. To support future needs, capture fisheries will need to be sustained and if possible enhanced, and aquaculture developed rapidly (Muir et al. 2005). However, a number of reasons have been suggested for the poor rate of growth in aquaculture development in the region. These include causes relating to fish consumption preferences, the general level of economic development in rural areas, the policy and governance environment, and limiting social factors (FAO, 2006), together with a lack of access to available information. Egypt has built the largest aquaculture industry in Africa, accounting for four out of every five fish farmed on the continent, according to FAO report, 2008. The report further reveals that Egyptian fish farms produce over 650,000 tons of finfish per year, or about 60 per cent of the country's total freshwater and marine fish production, providing a cheap source of protein for the country's over 80 million people.

International trade in fisheries products has been shown to have a positive effect on economic growth in many developing countries, stimulating increased production, generating foreign exchange which can be used for food imports, and enhancing the trade-based entitlements of people engaged in fishing and fish processing. Much of the discussion around the food security impact of international fish trade has focused on whether fish production for export reduces the amount of fish available for local consumption, presenting fish exports as a trade-off between foreign exchange earnings and domestic food security. Such a perspective, however, fails to take into account that foreign exchange from fish exports helps to finance imports of other foods, including fish products, and that production for export helps to raise the incomes of poor fisher-folk and people employed in fish processing, enabling them to achieve greater food security through enhanced purchasing power. In Thailand, for example, a decrease in rural poverty has been attributed to the export orientation of the fisheries sector and concomitant increase in the incomes of poor fishers. Fish processing for export can also generate employment, particularly among young women, though export-orientation in fisheries reduces the quantity of fish available to traditional fish processors (typically middle-aged women with little education), affecting their livelihoods.

The contribution of fisheries and aquaculture to development has consistently been underestimated both in national development and poverty reduction strategies and in international cooperation. (FAO, 2005), identify two factors which influence the degree to which fisheries are included in development policy in a given country: the sector's contribution to foreign exchange earnings and its contribution to food security and nutrition (measured by dependence on fish protein). The more reliant a country is on fisheries for its foreign exchange earnings and food security, the argument goes, the more likely that policy makers will recognise their importance and that this will be reflected in development policy. As farming and terrestrial livestock often, both generate more foreign exchange and are perceived to make a larger contribution to food security than other renewable resource sectors such as forestry and fisheries, they generally receive much more attention in national development strategies and donor priorities. When faced with resource allocation decisions, many governments prioritise water use for human consumption, agriculture, hydropower, and industry over inland fisheries and aquaculture. This is largely attributable to the perceived contribution of each sector to development, but also to the prevalence of single water-use systems. Encouraging multiple uses of water, however, can increase its productivity and allow for simultaneous development of several sectors.

Somalia is one of the least developed countries in Africa. It has also suffered from food shortages caused by a severe drought during the early 1970's. The Somali Ministry of Fisheries and the Coastal Development Agency (CDA) want to increase the fisheries catch to help alleviate the country's food shortage.

Somali fisheries are still largely undeveloped and play a minor role in the nation's economy. However, they could become important. Somali fishermen caught only about 11,000 metric tons (t) of fish in 1980, a small catch for a country with over $3,000 \mathrm{~km}$ of coastline. Most of the Somali catch is harvested near the north-eastern coast, between Alula and Bella. 
The Somali fishing fleet is largely artisanal. Cooperative fishermen have about 700 small boats (6 to $8 \mathrm{~m}$ long), and private fishermen operate an additional 100 boats of similar size. The Somali Government helped the fishermen buy and motorize these vessels under the country's 1974-78 development program. The only commercial vessels are operated by the state-owned company Somali-fish, which has II trawlers. These vessels are based in Kismayo and are about 23-27 m long. According to Ministry sources, none of these trawlers are currently operational, due to technical problems. The Government's recent development program has emphasized the formation of agricultural and fishery cooperatives for artisanal fishermen, as well as resettlement centers for displaced nomads. The Ministry and the CDA have organized 19 fishing cooperatives. Fishermen from these cooperatives harvest most of the country's catch, almost all of which is marine since Somalia lacks freshwater lakes and rivers. Somalia fishermen are required to sell their catch through the cooperatives at prices set by cooperative committees.

Puntland government of Somalia encouraging any creative attempt promoting the industries fishery of the region in geographical coastal of the Puntland, the state has the large coastal of the Somalia approximating, that enrich the kinds of the fish which is suitable to as consumption of the food. Large factory concerned with the fish production of Somalia was Laskory factory which is located Puntland. This factory established and invested Russia Government and this was the see able project implemented by near friendship country, the aim of the factory was to cover the fish need circumstances population of Somalia.

Developing and encouraging the industries is the fundamental mobilization resources and process the fish to handle advantage of the fish, according the biodiversity of Puntland kinds of the fish is the profitable to invest industries process the fish.

In an effort identify the potential commercial that shows the fill so that has undertaken focusing primarily on commercial viability, but wider issues such as development and enhancing the investment industries of Puntland, chamber of commerce is one indicator that shows awareness to the stakeholders to lead to encourage the investment of the industries, this literature gives reliable guidance that support you approach you passing in order to invest the profitable industries. The purposes of the study are therefore to identify potential investment within the aquaculture of the Puntland government of Somalia, fish handling and processing sectors, to identify potential opportunities. The objectives of this research are to enables the thinkers to invest the industries understand the potential opportunities needs to fill in order to minimize or short down the poverty and unemployment of the youth to create economic recovery and development, which in time peace

\section{Statement of the Problem:-}

The Puntland fish processing firms has not yet developed the necessary technical and logistical capabilities that can exploit a wide range of the abundant inshore and offshore resources and Fishing is the one of the four main economic sources in Puntland and there is poor protection of Puntland fish processing firms. As a result, there are no industrial or recreational fisheries and the sector is exclusively based on artisanal capture that accounts for 100\% of the total fish production. According to research of assessment of the status of the artisanal fisheries in Puntland (A. J. Kulmiye, 2010) Fishing has not traditionally been an accepted economic activity for the Somalia people and in fact as recently as 40 years ago members of the traditional fishing communities were looked down upon to the extent that they were not allowed to marry into pastoralists and other non-fishing communities. Fish consumption was therefore limited to the fishing families and those living close to the coastal landing places. Although the Gulf of Aden port town of Bossaso has a vibrant fishing sector, the many challenges fishermen face there make it difficult to develop this industry into a major contributor to the economy. The FAO project addresses some of these problems in order to help establish a sustainable fishing industry. (Michael Savins, 2016) Head of the Fisheries Infrastructure and Fleet Renewal Unit in Bossaso, says the lack of cold storage facilities and the challenges involved in the proper handling of fish often lead to a high level of spoilage. According Ministry of Fisheries and Marine Resources with partnership of FAO (2014), found that despite Somalia have the largest coast in Africa it regarded as one of the lowest per capita fish consumption in the world; they further found that only $4 \%$ of the working force are engaged with the fishing firms, and hence this small percentage are faced by a number of problems including poor infrastructure, cultural practice, Capital Availability and technical skills availability. Moreover, there is need to study this problem by examining how such factors influence growth of the fishing processing firms as well as to propose better solutions that could enhance the fishing sector. There is no study done on factors influencing growth of fishing firms in Puntland. The study investigated the factors influencing growth of the fishing processing firms in Bosasso district. It provided strong arguments on how the variables such as culture, Capital availability and 
technical skills availability may directly or indirectly influence growth of the fish processing firms in Puntland with especial case study of Bosasso district in Bari region.

\section{General Objectives:-}

The overall objective of this study was to assess the factor influencing growth of fish processing firms in Puntland. Specific Objectives

\section{The specific objectives of the study should be:-}

1. To assess the influence of technical skills availability on growth of fish processing firms in Puntland

2. To Examine the influence of capital availability on growth of fish processing firms in Puntland

3. To find the influence of Culture on growth of fish processing firms in Puntland.

\section{Research Questions:-}

1. What is the influence of technical skills availability on growth of fish processing firms in Puntland?

2. What is the influence of capital availability on growth of fish processing firms in Puntland

3. What is influence of Culture on growth of fish processing firms in Puntland?

\section{Significance of the Study:-}

While it could not be possible to undertake a typical value chain analysis of the fisheries owing to the fundamental nature of fish marketing in Puntland, the study was described the existingfish marketing channels, internal and external fish supply chains, and the key players involved in these chains. The research was find out that marketing of locally producing canned fish is relatively well developed in comparison with fresh and frozen fish with a sizeable number of intermediaries operating between the canneries and consumers. An attempt has therefore been made to analyse the value added to the economic growth.

The resulting model and analysis of this research was also helping the Puntland government to gain exactly role of fishing in Puntland economic.

\section{Scope of the Study:-}

The study was focus on the general status of the aquacultures and fish processing firms in the selected current functioning firms in Puntland. these firms are focusing the growth of fish processing firms in Puntland, including study comprehensively past history of national Somalia industries fish and present activities conditions, resources basis, potential areas suitable for aquaculture, potential species to be formed, and level of competence within the fish processing firms in Puntland and generally in Somalia, as well as investment climate in the Puntland. Also, this study was under look at the main coastal towns in Puntland thus Bossaso, and other coastal town around Puntland. For this research scope was focusing the growth of fish processing firms in Puntland.

In geographically this study was based on, Bossaso district of Puntland state of Somalia.

\section{Limitations of Study:-}

The following are the limitations of the study:-

1. Lack of historical and current fishery data collection for the whole coastline which made it very difficult to get precise information on many aspects of the fisheries.

2. Unwillingness of some traders to provide honest answer on questions regarding market information such as costs, profits and etc. Which they see it as personal secrets.

3. Refusal by some actors to be interviewed for the study. e. Logistical and time constrain

\section{Literature Review:- \\ Introduction:-}

This chapter summarizes selected literature on factors influence on growth of fish processing firms, but with focus on Culture practice, Technical Skills Availability, capital Availability and their influence of growth on fish processing firms. Therefore, this chapter is based on previous printed information about growth of fish processing firms obtained from the internet through Google Scholar search engine. They consist of reports and studies conducted in different countries, mainly East-Africa countries, and European countries. 


\section{Theatrical Review:- \\ Theory: -}

Each of the selected three variables (cultural, Technical skill Availability and Capital Availability) of this study were guided by theories.

\section{Cultural theory model: -}

This theory was first introduced by (Hofstede, 1972), in this theory culture is measured in terms of individual and collective behaviour, it emphasizes personal rights and responsibilities, privacy, voicing one's own opinions,


Reciprocity is voluntary, self-initiated or self-motivated Members feel interconnected in a group orientation system which creates more group solidarity. Management can appeal to this group-level solidarity. Seventy-five percent of the world's population subscribes to some kind of collective outlook and approach. This theory believes that individual's cultural material and non-materials plays significant role in development, it urges that some cultures are friendly to development, for example, Japanese cultures directly relates to their development, the culture of confusion which made japan more developed society, it also urges that some cultures are not friendly with development, the theory further urges that continuity of cultures that are friendly with the development, while giving examples to other society, likewise, the theory model urges that culturally unfriendly societies should integrate and modernize their culture and to be in line with the modern world perspectives. Cultures freedom produces uncertainty, which leads to stress and anxiety. These cultures may seek to avoid uncertainty by increasing rules of behavior, this theory further suggests that many southern European countries, as well as Japan and Peru, tend towards uncertainty avoidance. Other countries (including many northern European countries) are, it is argued, better able to tolerate freedom and diversity without excess stress and anxiety, culture's rigidity and dogmatism are a function of the uncertainty avoiding dimension. This dimension also influences communication between individuals; particular direct or indirect forms of communication can be used to reduce uncertainty. examples to other society, likewise, the theory model urges that culturally unfriendly societies should integrate and modernize their culture and to be in line with the modern world perspectives. Cultures freedom produces uncertainty, which leads to stress and anxiety. These cultures may seek to avoid uncertainty by increasing rules of behaviour, this theory further suggests that many southern European countries, as well as Japan and Peru, tend towards uncertainty avoidance. Other countries (including many northern European countries) are, it is argued, better able to tolerate freedom and diversity without excess stress and anxiety, culture's rigidity and dogmatism are a function of the uncertainty avoiding dimension. This dimension also influences communication between individuals; particular direct or indirect forms of communication can be used to reduce uncertainty.

\section{Labour process theory:- \\ Technical Skills variable:-}

This theory is first introduced by (Ricardo, 1917) and late developed Marxist theory of the organization of work under capitalism. theory of value that argues that the economic value of a good or service is determined by the total amount of socially necessary labour required to produce it, rather than by the use or pleasure its owner gets from it. At present, this concept is usually associated with Marxian economics, although it is also used in the theories of earlier liberal economists such as Adam Smith and David Ricardo and later also in anarchist economics. According to Marx, labour process theory refers to the process whereby labour is materialized or objectified in use values. Labour is here an interaction between the person who works and the natural world such that elements of the latter are consciously transformed in a purposive manner. Hence the elements of labour process are; three-fold: first, the work itself, a purposive productive activity; second the object(s) on which that work is performed; and third, the instruments which facilitate the process of work. Labour Process Theory looks at how people work, who controls their work, what "skills" they use in work, and how they are paid for work. Braver man posits a very broad thesis: that under capitalism, management steals worker's skills, reduces the pleasurable nature of work and the power workers have through controlling skill, while cutting their wages by reducing their wages to those of unskilled workers and increasing the amount of exertion required from workers.

A key element of labour process theory is an analysis of the local systems of management and control, and an examination of how these are used to reduce the power of sections of the working class who hold work skills that aren't reproducible by unskilled labour or machine power 
The Lewis Theory of Development

Capital Availability:-

(Lewis, 1950) in the mid -1950s formulated one of the best known theoretical models of development that focused on the structural transformation of a subsistence economy. The model is based on the 1954 article from the Journal of the Manchester school of Economics. Basically, he conceptualized the economy in terms of the sectors, i.e. what he calls the capitalist sector and the traditional sector. The capitalist sector in his model provides the engine for growth of the economy and as the capitalist sector expands, economic growth and development expand. Initially, the traditional sector represents the large sector and the capitalist sector, the small one. This according to Lewis explains how the capitalist sector gets to grow large in size at theexpense of the traditional sector. Lewis looked at development as a process of the transformation of the traditional economy into a modern capitalist sector.

Conceptual Framework:-

The conceptual framework shows the relationship between the independent variables which are Technical Skill availability, Capital Availability and Culture, the dependent variable which is growth of fish processing firms. Figure 1 displays the diagrammatic representation of the relationship between the independent and dependent variables of this research

Independent Variables

Dependent Variable

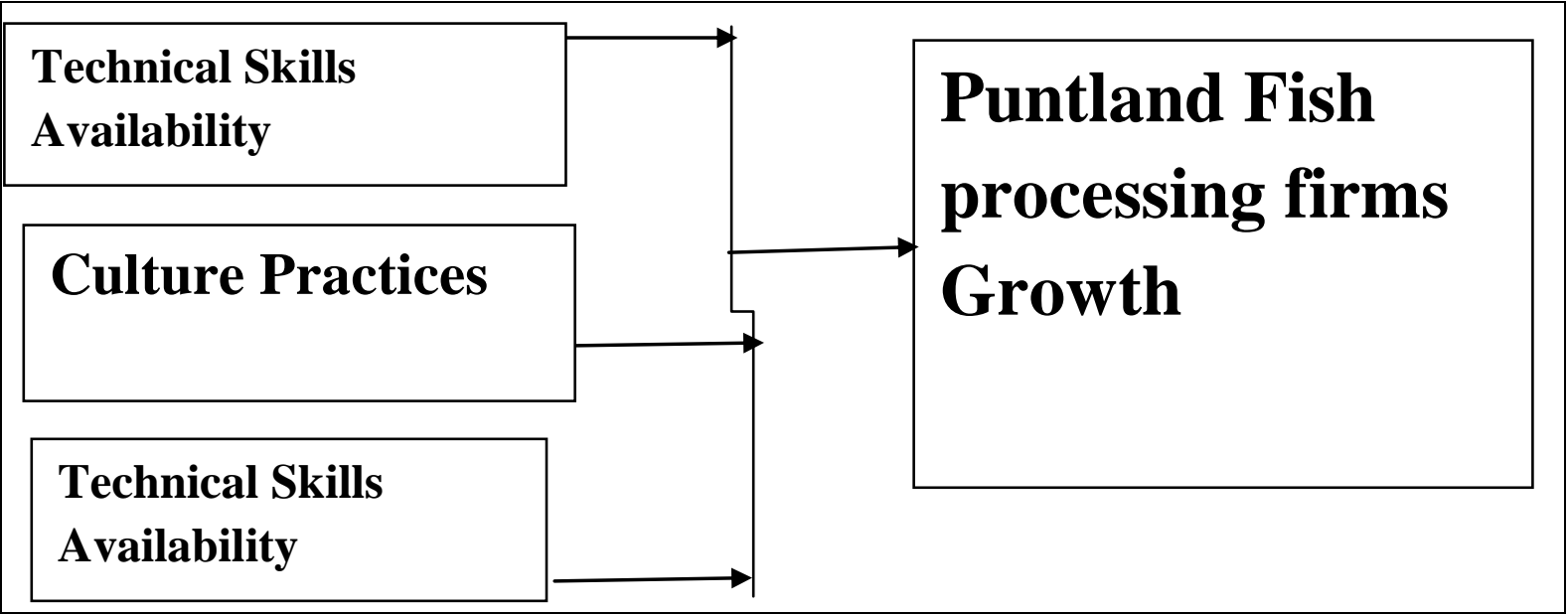

Figure 2.1

Broadly, culture is social heritage of a group (organized community or society). It is a pattern of responses discovered, developed, or invented during the group's history of handling problems which arise from interactions among its members, and between them and their environment. These responses are considered the correct way to perceive, feel, think, and act, and are passed on to the new members through immersion and teaching. Culture determines what is acceptable or unacceptable, important or unimportant, right or wrong, workable or unworkable.

In the past, cultural practice in study area have framed fishing as an inferior industry, and fish meat has been considered to be of a ,lower status"e than others. Recently though, there has been a shift that has seen a greater acceptance of fish and fishermen. Much of this has to do with communities increasingly recognizing the health benefits of eating fish. The healthfulness of fish has been promoted by local doctors. The study concluded that cultural practice has no influence on growth of the fishing industry in the study area. The study dealt with domestic market demand, banking services. Other challenges included limited fish exporting companies, lack of access to market information and lack of government subsidy to support for fishermen.

\section{Technical Skills Availability:-}

Administration and Management - Knowledge of business and management principles involved in strategic planning, resource allocation, human resources modelling, leadership technique, production methods, and coordination of people and resources. Education and Training - Knowledge of principles and methods for curriculum and training design, teaching and instruction for individuals and groups, and the measurement of training effects is one of the needs of the staff working fishing companies. 
The long-term ability of fishers to adapt to changes in the fishery as a result of development or management will also depend on the skills and education which they command. In many parts of the developing world, fishing communities are consistently among the people with the lowest levels of education. What is more, their skills are extremely specific to the fishing profession. This can make movement out of fishing very difficult.

From assessment of educational levels and skills within stakeholder communities affected by changes in fisheries, managers and decision-makers can determine what forms of education or training might be required as part of development packages in growth of fishing industries.

\section{Capital Availability:-}

Capital Availability is a fundamental driver of economic growth through both macroeconomic and microeconomic channels. The positive macroeconomic results occur by: increasing aggregate demand, replenishing the existing capital stock, raising productivity, fostering technological innovation, and facilitating job creation. The positive microeconomic results occur by influencing businesses capital investment decisions to increase revenue, profits, and the value of the firm.Current rationalization options for challenges on growth of small fishing firms include significant allocations of harvester quota to processors, justified as compensation for "capital Availability." This article discusses the origin of the concept of capital Availability, its use in other policy settings, preconditions, measurement, and remedies for addressing it. Our main finding is that rationalization of fisheries is unlikely to generate significant processing due to capital Availability in Puntland. Most capital involved in fisheries processing is malleable and not likely to be devalued as a result of rationalization. If policy makers nevertheless judge it desirable to consider compensation, a legitimate process would tie compensation to anticipated or demonstrated capital losses. Current policies proposed on the U.S. West Coast to transfer harvester quota are arbitrary and unsupported by empirical estimates of the magnitude of the problem. They are likely to generate important spill over effects that could negate some of the intended benefits of rationalization

\section{Empirical review of relevant studies:- Culture Practices:-}

According to research study of (Mumin F. A., 2017) In the past, cultural practice in study area have framed fishing as an inferior in fishing firms, and fish meat has been considered to be of a „lower status ${ }^{\text {ee }}$ than others. Recently though, there has been a shift that has seen a greater acceptance of fish and fishermen. Much of this has to do with communities increasingly recognizing the health benefits of eating fish. The healthfulness of fish has been promoted by local doctors. The study concluded that cultural practice has no influence on growth of the fishing industry in the study area. The study dealt with domestic market demand, banking services. Other challenges included limited fish exporting companies, lack of access to market information and lack of government subsidy to support for fishermen According to research of ( Kimathi,Antoney. 2013, factors affecting profitability of fish farmings under economic stimulus programme, 2013) in Tigania east district Meru Country in Kenya (IOSR Journal of Business and Management (2013) that influence fish firms Most of the respondents felt that when men are controlling income, there is little fish consumption in their households. They also felt that fish firm was the work of their spouses but a further 51\% who operated fish firm's business felt that men controlling income had nothing to affect fish consumption. This result maybe associated to those men who due to their cultural foods have not fully absorbed fish into their main stream diets Factors Affecting Profitability of Fish Firm Under Economic Stimulus Programme in hence have further left the task of fish rearing to their spouses where they happen to have a fish pond. Women being able to access their credit and enlightened more on proper feeding habits/ diets disregarded the norms surrounding consumption of fish and adopted its consumption. District fisheries officer also observed that some cultural practise though to a less magnitude affected fish consumption. Such practises include the eating habit which termed fish cooking and eating as length procedure, men controlling units of ownership in the family, and availability of other meat sources especially in the district which practise pastoralism and mixed firms. Thus, it can conclude that some cultural beliefs and practices may affect fish consumption patterns in Tigania East district tough not to a large extent.

According to thesis of (Fellner, 2008) Study of China and Latin America (Amira Fellner, 2008) historical developments and a region's culture have an extreme impact on a country's economy (Greif, 1994). In addition, a region's culture strongly defines the history of economic development. Thus, culture is colossally important in demonstrating traditions of the society from past to present. Cultural perspectives provide researchers with references, which exemplify values, attitudes, and behaviours that influence economic development in China and Latin America. Culture is a combined reflection of politics and economics in any society. Culture can also be 
perceived as a type of productive force. As some Chinese scholars' claim, politics, economics and culture are the three gears of any society andonly when they move harmoniously can the whole society develop rapidly (Xuewen, 1997). The study of the interaction between culture and economic development is not new. However, economists often overlook the role of culture in the economic development of countries. Culture generates assets such as skills, products, expression and insights that contribute to the social and economic wellbeing of a community. Both culture and values shape economic development.

According to (Sen, 1997). Culture is measured by indicators of individual values and beliefs, such as trust and respect for others, and confidence in individual self-determination. Culture, like institutions, is a vague concept. Culture corresponds to the social norms and individual beliefs that sustain equilibria as focal points in repeated social interactions (Greif, 1994). In this interpretation, culture is one aspect of broadly defined institutions and contributes to shape individual incentives. A more radical view is that culture directly influences individual behaviour through values and preferences (Akerlof and Kranton, 2000). Others have pointed out that social norms and individual values could interact in systematic fashions (Benabou and Tirole, 2006). 6 Sociologists have tended to believe that cultural norms pervade economic life and that to understand economy it cannot be separated from culture. Many economists point out that the differences in economic performance from one society to another are better explained by differences in institutions and in the policies undertaken by those institutions than by cultural factors (Bell, 1994). Culture also affects the ability of societies to create and properly manage institutions. For example, in the post-war period Japan, South Korea and other East Asian countries employed industrial policies, in which the state rather than the market allocated credit to national industries to encourage economic growth. The notion of culture has witnessed changes from time to time. More than one hundred years ago, E.B. Taylor defined culture in his book Primitive Culture where he defined culture as the complex whole which included knowledge, belief, art, morals, and customs acquired by man as a member of society (Greif, 1994). In the middle of this century, A.L. Kroeber described culture in his Anthropology as consisting of speech, knowledge, and beliefs that is learned from other man and elders (Kroeber, 1948). In Culture: A Critical Review of Concepts and Definitions, A.L Kroeber and Clyde Kluckhohm stated that culture consists of patterns, both explicit and implicit of behaviour acquired and transmitted by symbols, consisting the distinctive achievements of human groups, including their embodiment in artefacts (Kluckhohm, 1952). They said that the essence of culture consists of traditional ideas. In short, culture is the total social heritage acquired by man as a member of the society. Culture is shared and distinctive forms or patterns, that shapes human behavior, and its essence is the values embodied in the beliefs of the people. This makes value 7 orientation patterns the essential features of culture (Alexander and Kumaran, 1992). In discussing the relationship between culture and development, Gao Xian raises the issue of macro-culture. He points out that macroculture includes not only culture in the narrow sense (art and literature), but also culture in the broadest sense (Xian, 1996). Therefore, the macro-culture approach to development is a holistic exploration of the development process, material and moral, current and historical partial and total. According to Xian, the macro-culture approach primarily addresses the issue of an objective attitude towards tradition and their relationship between traditional culture and modernization development (Xian, 1996). In discussing the notion of culture, we also need to pay attention to a nation's tradition. According to Xian, tradition is what a society inherits from its history and which forms the norms of morality, concept of values, modes of behaviour, methods of thinking and ideas (Xian, 1996). This serves as the foundation of the cultural identity of that particular society.

\section{Technical Skills Availability:-}

Human resources score the lowest followed closely by political stability and efficient labour markets. This are key factors that underlay the development and growth of any sector anywhere on the globe on if these are not in place, the probability of a country or an economic sector achieving any form of development and growth are next to impossible. It therefore cannot be over emphasized that the human investment is the priority area to focus on if any meaningful growth and development in the Puntland marine and fisheries sectors is to be achieved. Any intervention that does not address this aspect will only achieve superficial and short-term gains.

According to research of (Kluckhohm, 2016) report on proposed Puntland fisheries value chain upgrading strategy) lack of a pool of highly skilled manpower to run the private sector and public-sector in terms of driving private enterprise and public-sector reforms that would have synergistic effect on each other and result to a working marine and fisheries market for Puntland. currently Puntland has experience a brain drain over the past three decades and at the same time the current education system is not sufficiently qualified to turn out individuals with the skills and knowledge required to meet the present challenges. 
according to research of (factors affect profitability of fish farms under economic stimulus programme in Tigania east district Meru country in Kenya, 2013) (IOSR journal of business and management, 2013) the research has found out that training of fish farmers to have a positive relationship to the growth of the fishing industry, therefore, the researcher recommended, that more elaborate programs to train fish farmers on management skills and modern technology should be developed to enable them. as shows the study, fisheries head in the district reported that farmers are not adequately equipped with technical skills due to the low staffing in the district and lack of funds to facilitate trainings and field visits to impact the knowledge on farmers. majority of fish farmers also felt that extension officers visited their farms rarely hence they don't have enough technical knowhow to take care of their fish farm. a further $66 \%$ of those farmers who felt that extension officer visited them frequently claimed that they had adequate technical knowhow to take care of their fish farm. Thus, the more an extension officer visits a farmer the more he/she is likely to report better known on how to tender the fish farm (appendix f, figure 4.2) thus clearly related services and in particular extension service is necessary to keep fish farmers educated on fish farm management. according to the talent, labour quality, and economic development (German Cubas B. Ravi Kumar and Gustavo Ventura, may, 2015), to calculate the relative importance of TFP, researchers measure the cross-country differences in the quality of workers, or labour quality for short. traditionally, labour quality has been measured using observations on schooling and returns to schooling. such measurements account for a small fraction of the differences in output per worker; see Caselli (2005) for a review. however, what if TFP differences include unmeasured labour quality differences? recent work follows two approaches to quantify this unmeasured component. one approach uses labour earnings of immigrants from different countries working in the U.S. labour market to quantify cross-country differences in labour quality. Hendricks (2002) and Schoolman (2011) are examples of this approach. the other approach involves developing theories of labour quality based on unobserved individual heterogeneity and disciplining the key parameters describing the heterogeneity with observations of U.S. labour earnings. Erosa, Koreshkova, and Restuccia (2010) is an example of this approach. in this paper, we take an alternative approach to the measurement of labour quality and the resulting implications for the importance of TFP. we use direct observations of the achievements of individuals prior to their entry into the labour force as an exogenous input to a theory of labour quality.

\section{Capital Availability:-}

According to Kimathi Antoney Njagi, I. C. (2013). Factors Affecting Profitability of Fish Farming Under Economic Stimulus Programme in Tigania East District, Meru County, Capital is the category of enterprises that provide materials, equipment, tools, knowledge and other supplies otherwise known as inputs that the rest of the businesses in the capital availability need to perform their operations. As shows the study, capital availability has important impact fish processing firm's growth and involved are availability of these factors, boats, spare parts for the boats, diesel to run the boats, fishing gear such as nets, hooks and line, ice. The main enterprises that provide the inputs are HDI Company in Bosaso which is a boat making company, individual fishermen who mainly lease out boats to fellow fishermen, businessmen running cold storage facilities who sell ice to fishermen and transporters, Yemenis fishermen who lease out boats, provide fuel and ice to the Somali fishermen. Importance of capital availability inputs are critical in the production process of any value chain as they determine the quality of production and yields or capacity to meet volumes of product demanded by a given market. Inadequacy of inputs of required capital will lead to low quality production, inefficiencies which increase cost of product and lead to inability to satisfy the market demand in terms of volumes.

Puntland Fisheries capital availability challenges around Puntland fisheries are on three areas; low level technology fishing gear (gill nets, hooks and line, rudimentary boats), wrong/inappropriate/banned fishing gear such as gill nets; inadequate access and use of ice and related cold chain infrastructure such as cold storage and finally limited number of input providers. Low level technology fishing gear that the Somali fishermen use and have access to has contributed to low catch levels, inordinate amount of time spent in the ocean fishing only to bring in a modest fish haul, significant by-catch such as dolphins and landing a limited range of fisheries species (tuna family, mackerel, groupers. Inadequate access to ice and related cold chain infrastructure such as cold storage has basically led to high post-harvest losses, low fish landing prices and, exploitation of Somali fishermen by Yemenis fish traders, low bargaining power in the market and high transactions cost on the part of Somali fishermen. Puntland has few input providers especially in boat making, fishing gear and cold storage and ice providers. There is only one boat manufacturer, HDI Ltd based in Bosaso. Most if not all fishing gear such as nets, lines and hooks are imported.

According to research of Threshold Effect of Capital Availability on Evidence from Seafood Processing Enterprises in the South-Central Region, Since the 60 years, the relationship between capital Availability and small firm growth 
has been the subject of considerable debate. The results of both theoretically and in empirical research formed three different perspectives on this relationship: (i) The capital Availability is unrelated to firm value. The South-Central region of Vietnam stretches across provinces and one coastal city, from Da Nang city to BinhThuan province. This is the area where Seafood processing sector is the one of the most prominent sector of Vietnam that significantly contributes towards the economy in terms of creating employment, exports and its contribution in GDP. Characteristics of area's seafood processing enterprises are small-scale, newly-established, semi-manual labour, backward processing technology. The number of listed companies on the stock market is limited. Further, they present low profitability, high bankruptcy risk due to continuous natural disasters, output markets of numerous barriers, limited capital and so on. During 2010-2012, with the increase of interest rates, financial costs have significantly gone up in this years, resulting in decreasing profit of the firms, many businesses have closed and declared bankruptcy. From the above practices, study the effect of capital structure on firm value for SEASCRs will help the enterprises making the decisions of enterprise capital restructuring more suitable. Specifically, how to use debt reasonably, in which case the increasing debt is effective, in which case the debt limit to reduce risk, reduce the risk of damage to enterprises. It is, therefore, of a particular, interest to investigate the relationship between capital structure and firm value in a sample of SEASCRs. In this study, for the purpose of indicating the extent of capital structure, the debt will have a positive effect, increasing enterprise value; the extent of capital structure, the debt will have negative effects, reducing the value of the enterprise. This research applies the threshold regression model of Hansen (1999) to construct the threshold regression model to investigate the effect of capital structure on firm value for Seafood Processing Enterprises in the South-Central Region of Vietnam. The paper is divided into six sections.

The capital availability of a firm concerns the mixture of debt and equity the firm uses in its operation. The relationship between capital Availability and firm growth has been the subject of considerable debate, both theoretically and in empirical research. Throughout the literature, debates have focused on whether there is an optimum capital availability for an individual firm or whether the proportion or level of debt usage is irrelevant or relevant to the firm's growth.

The next section reviews the results of previous theoretical and empirical research.

With reference of research for Nguyen Thanh Cuong, the capital availability is crucial for any business organization. The decision is important because of the need to maximize returns to various organizational constituencies, and also because of the impact such a decision has on an organization's ability to deal with its competitive environment. This study uses the advanced panel threshold regression model to examine the panel threshold effect of capital availability on firm value among 90 unlisted Seafood Processing Enterprises in the SouthCentralregion of Vietnam during 2005-2011 period. The findings of the study show the presence of triple threshold effect of debt ratio on firm value when BVE is selected to proxy firm value. However, when ROE is selected to proxy firm value, the result shows that there exists double thresholds effect between debt ratio and firm value. From these results, the author may conclude that the relationship between capital availability and firm value has a nonlinear relationship represents a convex parabola shape. In addition, this study provides new evidence on the existence of threshold debt ratio of $57.39 \%$ for unlisted Seafood Processing Enterprises in the South-Central region of Vietnam. This result supports the trade-off theory and the findings of previous authors, also as author's hypothesis in this study, implying that there exists an optimal capital Availability for each enterprise. For the control variables, according to empirical results, the size of total assets has a significantly positive effect on firm value. This finding supports author's hypothesis in this study, implying that the greater the size of total assets, that a firm have, the higher its firm value.

According to the (Egziabher, G. 2016). A simple example of this can be seen when a lumberjack upgrades from a standard axe to a chainsaw. Superior capital equipment directly makes individuals, businesses and countries more productive and efficient. Increased efficiency leads to economic growth. A business does not see an immediate increase in revenue when it develops capital goods. To make it economically viable to increase or improve the capital availability, a company must have a pool of saved funds to draw upon. This pool of funds needs to last until the new capital goods lead to additional revenue. Increased capital investment allows for more research and development in the capital structure. This expanding capital structure raises the productive efficiency of labour. As labour becomes more efficient, more goods are produced (higher GDP) and the economy grows. 


\section{Critique of the existing studies:-}

In order to analyses and synthesize information of previous studies relevant to this research of factors influence on growth of Fishing processing firms in Puntland state by focusing on the or ideas studies I would like to critique the several studies those we have cited in the empirical studies section.

There are numerous of studies previously talked about the factors influence on fishing sector growth while studies focus the Capital Availability, Technical skills Availability and Culture practice impacts and factors behind that effect for research topic which become very high over the word especially developing world. The Studies mostly have discussed the subject as whole but in Puntland related studies are very rare.

The empirical studies of this research focused on why and what caused lack of Growth of fishing processing firms in Puntland, and the different factors influence it, but did not conversed the solution that can be prevents to this scenario.

generation in Puntland because most of Somali youth in Puntland are thinking about how he/she would go to developed world (Europe, Australia and so on) instead of thinking about, creating new innovations to develop their own country and take-off from low development to developed country, technological advancement and the all consequences brought by Somali civil war and central State failure. So, this resulted that most Puntland farmers hire external labour such "Oromo" youth from Ethiopia and other Somali who came from south and central of Somalia, while their boys are jobless, this scenario caused that Puntland unemployment widespread became very high.

\section{Summary:-}

Infrastructure constraints: The Puntland Fishing sector is seriously lacking the necessary supporting infrastructure such as cold storages, processing plants, canning factories, accessible roads, facilities for boat repair and maintenance, etc. The establishment of such infrastructures could facilitate and help develop and expand the sector significantly. The infrastructure constraints are mainly related to the lack of access roads, cooling systems, and conservation. The major constraints are categorized as follows: National harbours, which could support fisheries, are missing. The only port Puntland has is Bossaso, that day-by-day hosts more than 20/30 national boats and half a dozen of medium Yemen fishing boats. Inadequate cooling systems, processing and preservation systems. 3. Absence of repair/maintenance facilities outside Bossaso

There are also small ice factories in Bossaso and Garowe which provide block ice to the towns and fishery communities, at least 10 such factories operate in Bossaso and one in Garowe. - In Eyl there are artificial ponds that are intended to recruit lobsters. The ponds are like aquaculture ponds and operate similarly, the difference is only the way they recruit species. These ones keep only living lobster either small or big ones, but not larva. Environmental constraints: Illegal, Unregulated and Unreported (IUU) fishing is increasing day by day and destroying coral reefs, fish nursery areas, capturing endangered species and deplete ting fish stock rapidly. Climate change like monsoons also could affect finfish, as the Southwest monsoon (May - mid September) could spoil and deteriorate marine products rapidly. Local demand: Internal demand for fishery products in Puntland is still very low, due to traditional diet (which is biased toward meat), lack of roads and transports to bring the products rapidly and safely to the internal areas. The implementation of a proper awareness campaign and the improvement of the food processing infrastructure as well as the creation of equipped fish markets would cause local demand to increase. Export constraints: The constraints are mainly lack of preservation, cooling systems, proper handling and as well as quality control, which is the most important component that gives certification to seafood (i.e. the MSC illustrated in the above paragraph).

\section{Research gaps:-}

Although there are same researchers done this topic before, but still, there is research gaps. According to the thesis research of Faisal Abdi Mumin about the factors affecting growth of the fishing industry in Puntland is not considered same variable of this topic such as.

1. Enquire Capital availability in fish processing firms

2. Lobar skill effect in fish processing firms in Puntland

3. Other research gap of above named research was area of case study, because the Eyl is the small district and it cannot take the representative of fishing industry growth in Puntland since it's people are smaller number of Puntland population. 
Therefore, this research will be considering for these variables and in whole fishing industry production sector in Puntland. There are other literatures of this topic but unfortunately, they were not considering in Somalia, since based on another country. Fishing industry growth is an important role for overall economic in Puntland, although we cannot have said overall there is no fishing sector growth in Puntland but, unfortunate when according to availability of fishing production, market, and investment there is not required growth standard. The Most factors affect the ingrowth of the fishing industries in Puntland are the piracy and illegal fisher's impact, which are currently stay in Somali's coastal area. Highly frequented recent years whereas foreign ships are beneficiaries of Somalia Sea through unlawful hunts, this illegitimate caused by to meet fear a lot of young Puntlander fishers from the illegal ship fishers within Puntland or Somalia Sea. On other hand, it seems there are no big business activities about innovation of fishing processing firm's growth of the Somali.

\section{ResearchMethodology:- Introduction:-}

This chapter focuses on the manner in which the research problem was investigating by referring to the sampling method, selection of respondents, data gathering instrument(s) (e.g. questionnaire) and the statistical techniques that was utilizing. In conjunction with the literature review which was undertaken and empirical analyses were conducting to assess the previous studies relevant to problem generated for the purpose of the study. In addition, the chapter will clearly identify the population and the target population which researcher will be questioning to assess their ideas toward research problem and articulate the research objectives.

\section{Research Design:-}

This research is the both quantitative and Qualitative study which concerned describing for its scope of the SocioEconomic factors influencing on growth fish processing firms in Puntland state, for the case study of fish processing firms in Bossaso district. The research was conducting in a quantitative approach; the aim of a quantitative is that the data was presented in the form of numbers (frequency tables and charts), which is objective and seeks precise measurement and an analysis of target population concepts. Forthe purposes of this research, a questionnaire was considering appropriate as data gathering instrument. Before the official research questionnaire there was some biographic questions those will reflect respondents profile. The purpose of biographical questionnaire is to obtain the staff information toward their professional (education level and experience), gender, nationality and age diversity while biographical diversity was support the validation of the data collected from them in terms of wider views and comprehensive experience.

\section{Research population:-}

The study targeted population was managers and Staff of fish processing firms, in case study of Bosasso districts. the target population was 128. The sample size was calculated using Slovin's formula 1960.

\section{Sampling frame:-}

The formula that was used for determining the sample size is by (Slovin formula, 1960) which is given as:

$n=$

$$
N
$$

$\mathrm{N}=\frac{128}{1+128 \times 0.052}=\frac{128=96}{1.32}$

Where

$\mathrm{n}=$ sample size

$\mathrm{N}=$ population size

$\mathrm{d}=$ Level of precision or sampling error (confidence interval)

Which is $95 \%$ ?

As indicated above formula the sample size was used to collect the questionnaire which was 96 respondents. The sample frame of this research was contained 96 members of the target population and were dividing as indicating the following paragraph.

The research respondents come from 15 managers of targeting firms and remaining 66 respondents from staff of the fish processing firms in Bosaso town and they were divided as following, from Mega Fish Company (5) staff, five (5) from SMAFSI Company, six (6) from HAFCO, six (6) from Sundus Fish Company, three (3) from Barfisco Fishing Company, four (4) from RaasiAhmar Fishing Company (RAFCO), six (6) from Somali Fishing Company (Somfal) Ltd, seven (7) from NEC-fish, three (3) Madani Fishing Company, four (4) from Barwaaqo Fishing Company, five (5) from Saada Fishing Company, six (6) from East Africa Fishing Company, two (2) from Puntland 
Fishing Company, three (2) from Durdur Fishing Company, and remaining three (2) from Garaad Fishing Company. the case study was done at Bosaso district. Researcher was using random sampling in order to collect information from target population who are most easily accessible and conveniently available to provide the required information.

\section{Sample and sampling technique:-}

The researcher was used for this study type of probability sampling method which Sample does known probability of being selected. The type of probability that were utilizing for this research involved simple random sampling.

a probability sampling design is incurring less expense, time, energy and access to suitable sites to measure every single item or site within the parent population or whole sampling frame. Therefore, an appropriate sampling strategy is adopted to obtain a representative, and statistically valid sample of the whole, and may be done to take advantage of the available respondents without the statistical complexity of a probability sample (Welman\& Kruger, 2001).

\section{Instrument:-}

The instruments, researcher used for data gathering a questionnaire, researcher was using questionnaire as a hand delivery word papers to extract the ideas of respondents in detail. The research questionnaire was constructing with twenty (10) positively stated statements or items. Every item in the questionnaire contains the liker scale from one to three.

Each item allows the sample of subjects to make a choice between five answers, namely:-

1. Strongly ag

2. Agree

3. Unsure

4. Disagree

5. Strongly Disagree

6. For the purpose of this study all responses are coded in the following manner:

7. Strongly agree $=$

8. Agree $=$

9. Unsure $=$

10. Disagree $=$

11. Strongly Disagree=

The questionnaire of this research was focus on the issues that need to be answered in order to comprehend the factors influenced growth of fish processing firms in Puntland.

\section{Data collection procedure:-}

There are many research methods to collect data in my research; despite the shortage of concrete research and studies previously done, both literature review and primary data through data collection with all target population was the data collection methodology of this study to achieve its intended objectives. The primary data collection had assisted in providing facts and figures for comparison and analysis while, the literature review providing a depth background information on existing records of the previous study.

\section{Secondary data collection:-}

The study started from gathering and secondary investigation all relevant secondary information using both tax book, and electronic academic documents (internet) by collecting factual statistics of relating to Socio-Economic factors influencing for research topic in Puntland state level activities.

\section{Primary data collection:-}

The researcher was using for this research study on Questionnaire, as main primary data collection techniques, while the questionnaire researcher was using as a hand delivery word question papers to haul out the ideas of respondents in detail.

\section{Data Processing and analysis:-}

The researcher was analysing the exact findings of the data collecting from the sample population by using statistical data analysis software type of "Statistical Package for the Social Sciences (SPSS) version 20" to analyse and present the data in this research, by selecting descriptive statistics which describes the raw data in a clear manner, with 
frequency tables, gross tab analysis and graphical illustrations to provide information on key demographic variables in this study.

The statistics was basing on examination of each question formulated for the research in order to discover the adequate enlightenment toward the problem of the study and articulate the research objectives obviously.

\section{Introduction:-}

This chapter exhibits data presentation analysis and discussions of findings. It summarizes the findingsSystematically as well as comparing and contrasting the possible relationships of the the-orifical andempirical literature and the overall objectives of the study. The analysis was done in accordance with theresearch objectives and variables of the study. The variables under the study were factors influencing Growth of fish processing firms in Bossaso town, Puntland. The analysis was presented using frequencies,percentages, tables and figures. It starts with the response rate, general information of the sample, and provides findings according to the following study objectives:

To investigate the influences of Cultural practices on growth of fish processing firms in Bosaso town, Puntland.

To identify the influence of technical skill availability on growth of fish processing firms in Bossaso town, Puntland. To assess the influences of capital availability on growth of fish processing firms in Bossaso town, Puntland.

\section{Response Rate:-}

A total of 96 respondents were sampled in the study. The response rate was $100 \%$ since a total of 96 responded. A total of 96 comes from, 17 company managers, and 79 staffs of fish companies in Bosaso which select by using random sample, were reached as planned initially, which is also $100 \%$. This response rate indicates exact representation of the sample and of the entire population.

\section{Chapter four \\ Research findings and discussion}

\section{Response Rate:-}

A total of 96 respondents were sampled in the study. The response rate was $100 \%$ since a total of 96 responded. A total of 96 comes from, 17 company managers, and 79 staffs of fish companies in Bosaso which select by using random sample, were reached as planned initially, which is also 100\%. This response rate indicates exact representation of the sample and of the entire population.

Demographic characteristic of the research respondents.

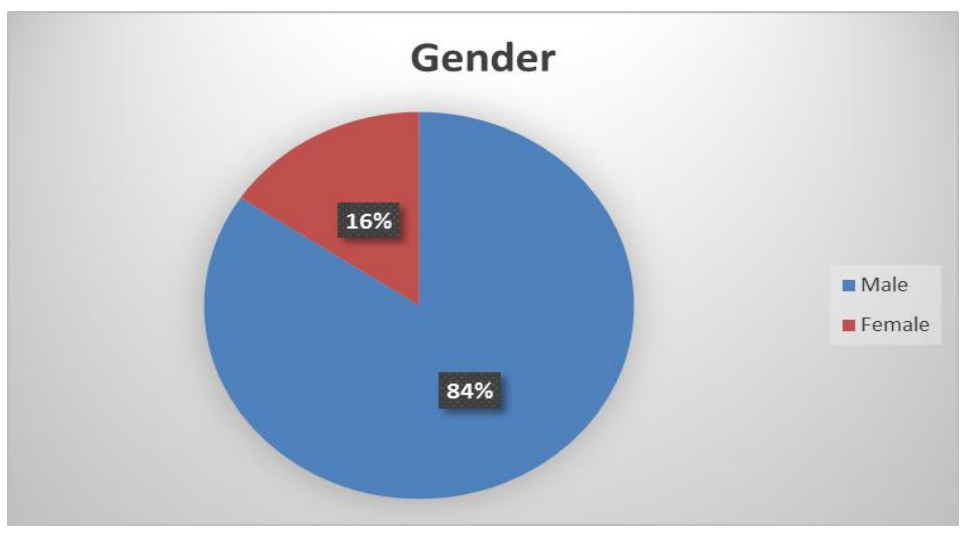

Figure 4:-Demographic characteristics of the respondents

According (figure 4.1.) $84 \%$ of the research respondents were male while $16 \%$ of the respondents were female. The male was more than female because of the most people working in the fish sector are male. in terms of age distribution of the target respondents, the findings were shown in figure 4.1.

Table 4:- Age break down of the research respondents

\begin{tabular}{|l|l|l|}
\hline Valid & Frequency & Percent \\
\hline $20-25$ & 10 & 10.4 \\
\hline
\end{tabular}




\begin{tabular}{|l|l|l|l|}
\hline $26-30$ & 16 & 16.7 \\
\cline { 2 - 3 } $31-35$ & 24 & 25.0 \\
\cline { 2 - 3 } $36-40$ & 27 & 28.1 \\
\cline { 2 - 3 } $41-45$ & 6 & 6.2 \\
\cline { 2 - 3 } $46+$ & 13 & 13.5 \\
\cline { 2 - 3 } Total & 96 & 100.0 \\
\hline
\end{tabular}

Table 4:-. demonstrates the age break down of the youth respondents $10.4 \%$ of the respondents were the age group of 20-25 years old, $16.7 \%$ of the respondents were between $26-30$ years old, $25 \%$ of the respondents were $31-36$ years old, $28.1 \%$ of the respondents were $36-40$ years old, $6.2 \%$ of the respondents were group of $41-45$ years old and the rest $13.5 \%$ were 46 and above years old.

\begin{tabular}{|l|l|l|l|}
\hline \multicolumn{3}{|l|}{ Table 4:- Marital status of research respondents } \\
\hline Valid & Frequency & Percent \\
\hline Married & 63 & 65.6 \\
\cline { 2 - 3 } Single & 14 & 14.6 \\
\cline { 2 - 3 } Widow & 9 & 9.4 \\
\cline { 2 - 4 } Divorced & 10 & 10.4 \\
\cline { 2 - 3 } Total & 96 & 100.0 \\
\hline
\end{tabular}

As shows the above table (Table 4.2), the Marital status of the research respondents which $65.6 \%$ were Married, respectively, $14.6 \%$ were single, other $9.4 \%$ were widow and remain 10.4 were divorced.

In this study, respondents were requested to indicate their levels of education in the questionnaires. In response, they indicted their level of education as shown in table 4

\begin{tabular}{|l|l|l|l|}
\hline \multicolumn{2}{|l|}{ Table 4:- Educational Level of the rearch respondents } \\
\hline Valid & Frequency & Percent \\
\hline Primary & 22 & 22.9 \\
\cline { 2 - 4 } Secondar & 35 & 36.5 \\
\cline { 2 - 4 } Bachelor & 16 & 16.7 \\
\cline { 2 - 4 } Degree & 2 & 2.1 \\
\cline { 2 - 4 } Master & 21 & 21.9 \\
Degree & 96 & 100.0 \\
Other & & \\
Total & & \\
\hline
\end{tabular}

Table 4 indicates the education level of the research respondents which $22.9 \%$ of the respondents were either pursuing or pursued Primary Level, similarly, $36.5 \%$ had secondary school education, $16.7 \%$ were having bachelor degree level of education, $2.1 \%$ of the respondents were Master degree level, and remain of 21.9 were others.

The influence of culture practices on growth of fish processing firms:-

The first variable of the study was to investigate the influences cultural practices on growth of fish processing firms in Bossaso town, Puntland. To achieve the objective of this variable, the respondents were asked the following statements

Table 4.4: According to our Culture, we don't eat fish.

\begin{tabular}{|l|l|l|l|}
\hline Valid & Frequency & Percent \\
\hline Strongly & 13 & 13.5 \\
\cline { 2 - 4 } Disagree \\
\cline { 2 - 4 } Disagree \\
\cline { 2 - 4 } agree & 24 & 25.0 \\
\cline { 2 - 4 } $\begin{array}{l}\text { Strongly } \\
\text { agree }\end{array}$ & 57 & 59.4 \\
\cline { 2 - 4 } Total & 2 & 2.1 \\
\hline
\end{tabular}


Table 4.4. indicates respondents were asked statement of according to our culture, we don't eat fish and $13.5 \%$ of the respondents answered strongly disagreed, $25.0 \%$ of the respondent replied disagreed, $59.4 \%$ of the respondents answered agree, while the remaining $2.1 \%$ responded strongly agreed. Therefore, the study found that individual are not consumes fish foods, in regarding of culture. According to the individual interviews, Fishing has not traditionally been an accepted economic activity for the Somalia people and in fact as recently as 40 years ago members of the traditional fishing communities were looked down upon to the extent that they were not allowed to marry into pastoralists and other non-fishing communities (A. J. Kulmiye, 2010).

\begin{tabular}{|l|l|l|l|}
\hline \multicolumn{3}{|l|}{ Table 4:- Culturally, People are more prestigiously employed in other areas nor fish industry } \\
\hline Valid & Frequency & Percent \\
\hline Disagree & 14 & 14.6 \\
\cline { 2 - 4 } Unsure & 22 & 22.9 \\
\cline { 2 - 4 } $\begin{array}{l}\text { Agree } \\
\text { Strongly }\end{array}$ & 57 & 59.4 \\
\cline { 2 - 4 } agree & 3 & 3.1 \\
\cline { 2 - 4 } Total 1 & 96 & 100.0 \\
\hline
\end{tabular}

Table 4.5. indicates respondents were asked statement of culturally, people are more prestigiously employed in other areas nor fish industry, and $14.6 \%$ of the respondents answered disagreed, $22.9 \%$ of the respondent replied unsure, $59.4 \%$ of the respondents answered agree, while the remaining $3.1 \%$ responded strongly agreed. Therefore, the study found that the people working other areas have more prestigiously rather than of fishing sectors in culturally.

\begin{tabular}{|l|l|l|l|}
\hline \multicolumn{2}{|l|}{ Table 4:-For Our culture, we don't eat canned fish foods } \\
\hline Valid & Frequency & Percent \\
\hline Strongly Disagree & 2 & 2.1 \\
\hline Disagree & 21 & 21.9 \\
\hline Unsure & 2 & 2.1 \\
\hline Agree & 70 & 72.9 \\
\cline { 2 - 4 } & Strongly Agree & 1 & 1.0 \\
\cline { 2 - 4 } & Total & 96 & 100.0 \\
\hline
\end{tabular}

According to the Table 4.6, the respondents were asked statement of, for our culture, we don't eat canned fish foods, so, in regarding of this enquire $2.1 \%$ of the respondents were answered Strongly disagree, $21.9 \%$ of the respondents were answered disagree, $2.1 \%$ of the target population answered unsure, while $70 \%$ of respondents were said agree and remaining $1 \%$ said strongly agree. So, according for the research result of above table, $71 \%$ of the people living study area agree that, we are not eating canned fish foods in regarding in our culturally. Although fish is plentiful in the waters off the Somali coast, Somalis generally do not like fish due to the traditional aspects. 


\section{A. Figure 4.2 Relationship Between Culture and growth of Fish processing firms}

the influence of technical skill availability on growth of fish processing firms:-

The Second variable of the study was to investigate the influences Technical Skill Availability on growth of fish processing firms in Bossaso town, Puntland. To achieve the objective of this variable, the respondents were asked the following statements.

Table 4.7:We don't have appropriate technically Skill for fish

\begin{tabular}{|l|l|l|l|}
\hline & & Frequency & Percent \\
\hline \multirow{4}{*}{ Valid } & Disagree & 1 & 1.0 \\
\cline { 2 - 4 } & Agree & 70 & 72.9 \\
\cline { 2 - 4 } & Strongly agree & 25 & 26.0 \\
\cline { 2 - 4 } & Total & 96 & 100.0 \\
\hline
\end{tabular}

For Our culture, we don't eat canned fish foods

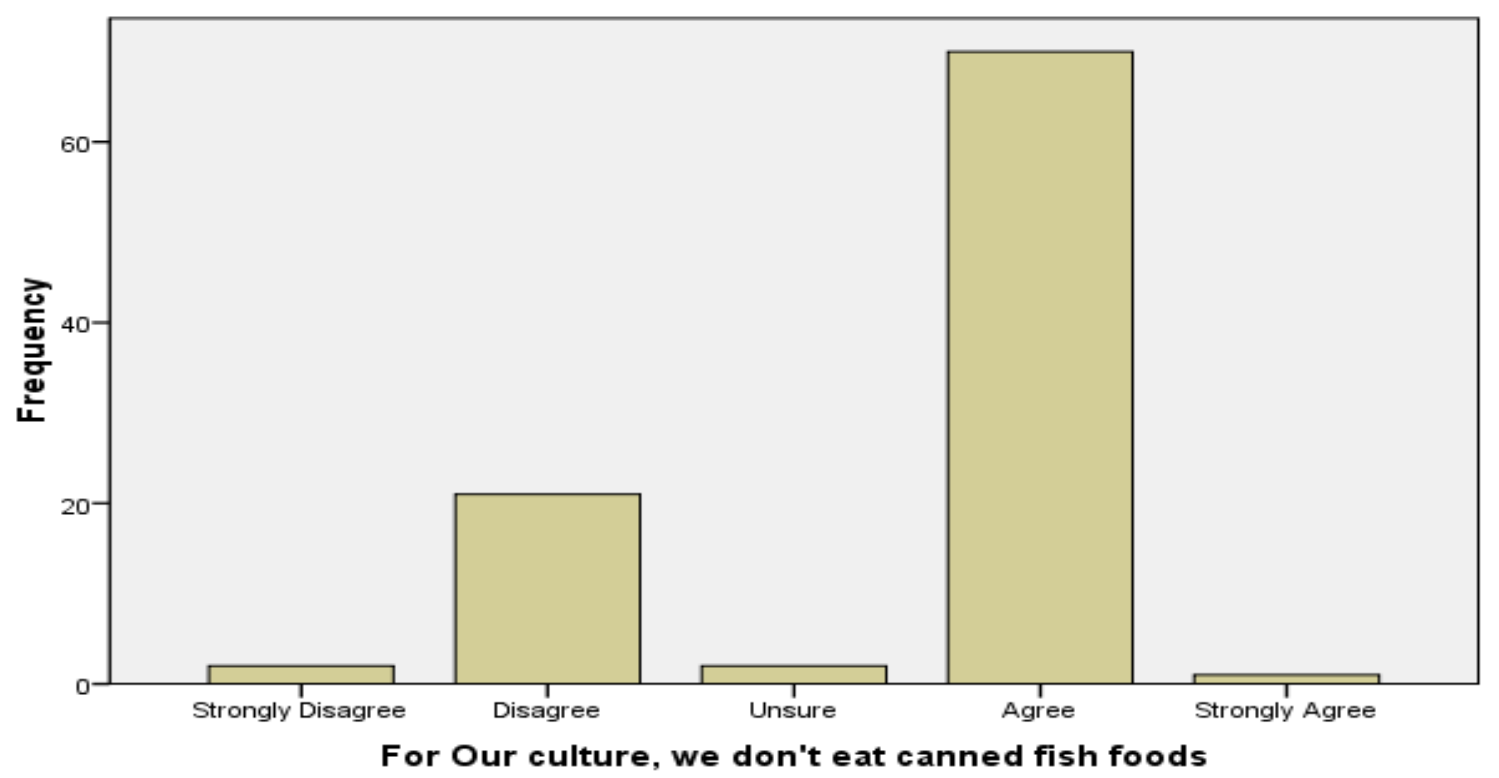

According figure 4.2 which present the result of research population, there is significant relationship between Culture practices and growth of fish processing firms in Puntland. In support study of Food and cultural practices of

the Somali community, (Metro South Health, 2015), Food choices can be influenced by geography as well as culture and religion. For example, in Somali, fish is commonly eaten by people who live in coastal regions.

According to table 4.7, the research respondents were asked the statement which said, we don't have the appropriate technically skill for fish, and $72.9 \%$ of the total respondents were answered agree, $26 \%$ were answered strongly agree while $1 \%$ were answered disagree. the study found that the small firm of fish processing in bosaso town, they were not having appropriate technical skill for the fish. The low skills and capacities on the part of private sector actors (fishermen, processors, input providers, distributors) at all functions in to respond to and exploit present and emerging market opportunities (amos j. waweru, 2016).

\begin{tabular}{|l|l|l|l|}
\hline Table 4.8: We don't know how to add value to fish \\
\hline \multirow{4}{*}{ Valid } & Disagree & Frequency & Percent \\
\cline { 2 - 4 } & Unsure & 20 & 20.8 \\
\cline { 2 - 4 } & Agree & 9 & 9.4 \\
\cline { 2 - 4 } & Strongly Agree & 62 & 64.6 \\
\cline { 2 - 4 } & Total & 96 & 5.2 \\
\hline
\end{tabular}


According to Table 4.8, the research respondents were asked the statement which said, we don't know how to add value to Fish, and $64.6 \%$ of the total respondents were answered agree, $5.2 \%$ were answered strongly agree while $20.8 \%$ were answered disagree and remain $9.4 \%$ answered unsure. So, according the result of above table, the study found that, the most of the staff of the fish firm in Bosaso town do not know how to make value for the fish in the market as to satisfaction to customer their product.

\begin{tabular}{|l|l|l|l|}
\hline \multicolumn{2}{|l|}{ Table 4.9: We don't have appropriate fish customer care } \\
\hline \multirow{4}{*}{ Valid } & Strongly Disagree & Frequency & Percent \\
\cline { 2 - 4 } & Disagree & 29 & 3.1 \\
\cline { 2 - 4 } & Unsure & 9 & 30.2 \\
\cline { 2 - 4 } & Agree & 44 & 9.4 \\
\cline { 2 - 4 } & Strongly Agree & 11 & 45.8 \\
\cline { 2 - 4 } & Total & 96 & 11.5 \\
\hline
\end{tabular}

According to Table 4.9, the research respondents were asked the statement which said, we don't have appropriate fish customer care, and $45.8 \%$ of the total respondents were answered agree, $11.5 \%$ were answered strongly agree while $9.4 \%$ were answered unsure, $30.2 \%$ of the respondents said disagree and remain $3.1 \%$ answered strongly disagree. So, according the result of above table, the study found that, $57.3 \%$ of the respondents they were agree that, there is poor quality of the customer care for the staff of the fish processing firm in Bosaso town.

\section{B. 4.4 the influence of Capital Availability on growth of fish processing firms}

The last variable of the study was to investigate the influences of Capital Availability on growth of fish processing firms in Bossaso town, Puntland. To achieve the objective of this variable, the respondents were asked the following statements.

\begin{tabular}{|l|l|l|l|}
\hline \multicolumn{2}{|c|}{ C. Table 4.10: We don't have appropriate cold storage for fish } \\
\hline \multirow{4}{*}{ Valid } & & Frequency & Percent \\
\hline \multirow{3}{*}{ Total } & Disagree & 1 & 1.0 \\
\cline { 2 - 4 } & Agree & 61 & 63.5 \\
\cline { 2 - 4 } & Strongly Agree & 34 & 35.4 \\
\cline { 2 - 4 } & & 96 & 100.0 \\
\hline
\end{tabular}

According to the table 4.10, the respondents were asked statement of, we don't have appropriate cold storage for fish, so, in regarding of this enquire $2.1 \%$ of the respondents were answered disagree, $63.5 \%$ of the respondents were answered agree, and remaining $35.4 \%$ said strongly agree. so, according for the research result of above table of 4.11, 99\% of the people living study area agree that, we don't have appropriate cooling system equipment for fish storage, and this is the biggest challenges which face the growth of the small fish firms in the Bosaso, since there is not proper way they can keep fish for long time. for this result study found that, there is poor protection of fish storages. the cold storage and processing facilities were looted and/or destroyed, some fell into disuse and disrepair, cooperatives ceased to exist and fish markets failed (Amos j. Waweru, 2016).

\begin{tabular}{|l|l|l|l|}
\hline \multicolumn{4}{|l}{ D. Table 4.11: We don't have land Capital that our business required } \\
\hline \multirow{4}{*}{ Valid } & & Frequency & Percent \\
\cline { 2 - 4 } & Strongly Disagree & 3 & 3.1 \\
\cline { 2 - 4 } & Disagree & 13 & 13.5 \\
\cline { 2 - 4 } & Unsure & 1 & 1.0 \\
\cline { 2 - 4 } & Agree & 38 & 39.6 \\
\cline { 2 - 4 } & Strongly Agree & 41 & 42.7 \\
\cline { 2 - 4 } & Total & 96 & 100.0 \\
\hline
\end{tabular}

According to the Table 4.11, the respondents were asked statement of, we don't have land capital that our business required, so, in regarding of this enquire $39.6 \%$ of the respondents were answered agree, $42.7 \%$ of the respondents were answered strongly agree, $1 \%$ of the respondents were answered unsure, $13.5 \%$ of the respondent were said disagree and remaining $3.1 \%$ said strongly disagree. So, according for the research result of above table of 4.12, $82.3 \%$ of the people living study area agree that, we don't have land capital, and this is the one of the challenges which face the growth of the small fish firms in the Bosaso. According to the individual discussions (waweru, J. 2015). Poor road infrastructure has severely limited not only market access; landed catch is unable to find its way to the hinterland of the country because of either poor roads or non-existent roads. This combined with the fact that 
many marine and fisheries distributors do not have access to cold-chain facilities especially reefer trucks compound the problem

\begin{tabular}{|l|l|l|l|}
\hline \multicolumn{6}{|l|}{ E. Table 4.12: We don't have financial investment our business required } \\
\hline \multirow{3}{*}{ Valid } & Disagree & Frequency & Percent \\
\cline { 2 - 4 } & Agree & 2 & 2.1 \\
\cline { 2 - 4 } & Strongly Agree & 27 & 28.1 \\
\cline { 2 - 4 } & Total & 67 & 69.8 \\
\hline
\end{tabular}

According to the Table 4.12, the respondents were asked statement of, we don't have financial investment that our business required, so, in regarding of this enquire $28.1 \%$ of the respondents were answered agree, $69.8 \%$ of the respondents were answered strongly agree, and remaining $2.1 \%$ said disagree. So, according for the research result of above table 4.13 , the $97.9 \%$ of the people living study area agree that, we don't have financial investment that required their business as they make growth of business, and this is the one of the challenges which face the growth of the small fish firms in the Bosaso. Somali fishermen are among the poorest and most marginalized members of Somali society. Empowering them with greater knowledge about fishing and preservation methods and providing them with access to better equipment could significantly increase their standard of living and boost food security (Spivak, Kaija. SHURAAKO Study).

\begin{tabular}{|l|l|l|l|}
\hline \multicolumn{3}{|l|}{ F. Table 4.13: How many years have been working your company in business of fish sector } \\
\hline \multirow{4}{*}{ Valid } & & Frequency & Percent \\
\cline { 2 - 4 } & $0-2$ & 9 & 9.4 \\
\cline { 2 - 4 } & $2-4$ & 18 & 18.8 \\
\cline { 2 - 4 } & $4-6$ & 31 & 32.3 \\
\cline { 2 - 4 } & $6-12$ & 38 & 39.6 \\
\cline { 2 - 4 } & Total & 96 & 100.0 \\
\hline
\end{tabular}

In Table 4.13, asked respondent question of how many years have been working your company in business of fish sectors. 9.4\% of the respondent were said 0-2 Years, $18.8 \%$ were answered 2-4 years, 32.3\% were answered 4-6 years and remaining $39.6 \%$ of the research respondents were answered 6-12 years or more. The aim of this question was to obtain the company experience for business of fishing sector and relationship between time business growth.

\begin{tabular}{|l|l|l|l|}
\hline \multicolumn{3}{|c|}{ G. Table 4.14: In Average, how much of fish your company producing per a day } \\
\hline & & Frequency & Percent \\
\hline \multirow{4}{*}{ Valid } & less than 50 & 6 & 6.2 \\
\cline { 2 - 5 } & $50-100$ & 24 & 25.0 \\
\cline { 2 - 5 } & $100-150$ & 38 & 39.6 \\
\cline { 2 - 5 } & $150-200$ & 15 & 15.6 \\
\cline { 2 - 5 } & $200-250$ & 10 & 10.4 \\
\cline { 2 - 5 } & $250-300$ & 1 & 1.0 \\
\cline { 2 - 5 } & $300+$ & 2 & 2.1 \\
\cline { 2 - 5 } & Total & 96 & 100.0 \\
\hline
\end{tabular}

In above Table of 4.14, research respondents were asked the statement which says, in average, how much of fish your company producing per a day, in this statement has been divided seven different categories as shows the above table. $6.2 \%$ of the research sample population were answered less than $50 \mathrm{kgs}$ per a day, $25 \%$ of the respondents said $50-100 \mathrm{Kgs}$ per a day, $39.6 \%$ of the respondents were answered $100-150 \mathrm{Kgs}, 10.4 \%$ of the research respondents were answered $150-200 \mathrm{Kgs}$ per a day, while the $1 \%$ of the respondents said $250-300$ and remaining $2.1 \%$ were category of $300 \mathrm{kgs}$ and plus.

\begin{tabular}{|l|l|l|l|}
\hline \multicolumn{3}{|l|}{$H$. Table 4.15: How is the consumption of the fish compared to previous decades } \\
\hline & & Frequency & Percent \\
\hline \multirow{3}{*}{ Valid } & increasing & 11 & 11.5 \\
\cline { 2 - 4 } & Decreasing & 48 & 50.0 \\
\cline { 2 - 4 } & no change & 25 & 26.0 \\
\hline
\end{tabular}




\begin{tabular}{|l|l|l|l|}
\hline & not know & 12 & 12.5 \\
\cline { 2 - 4 } & Total & 96 & 100.0 \\
\hline
\end{tabular}

In Table 4.15, research respondent was asked, how is the consumption of the fish compared to previous decades, 11.5 of the respondents were answered increasing, $50 \%$ of the respondents were said decreasing, while $26 \%$ were answered for this statement no changes and remaining $12.5 \%$ were answered not know. In regarding for above data, study found that fish consumption was decreasing recently decades.

Figure 4.3 consumption of the fish compared previous decades

How is the consumption of the fish compared to previous decades

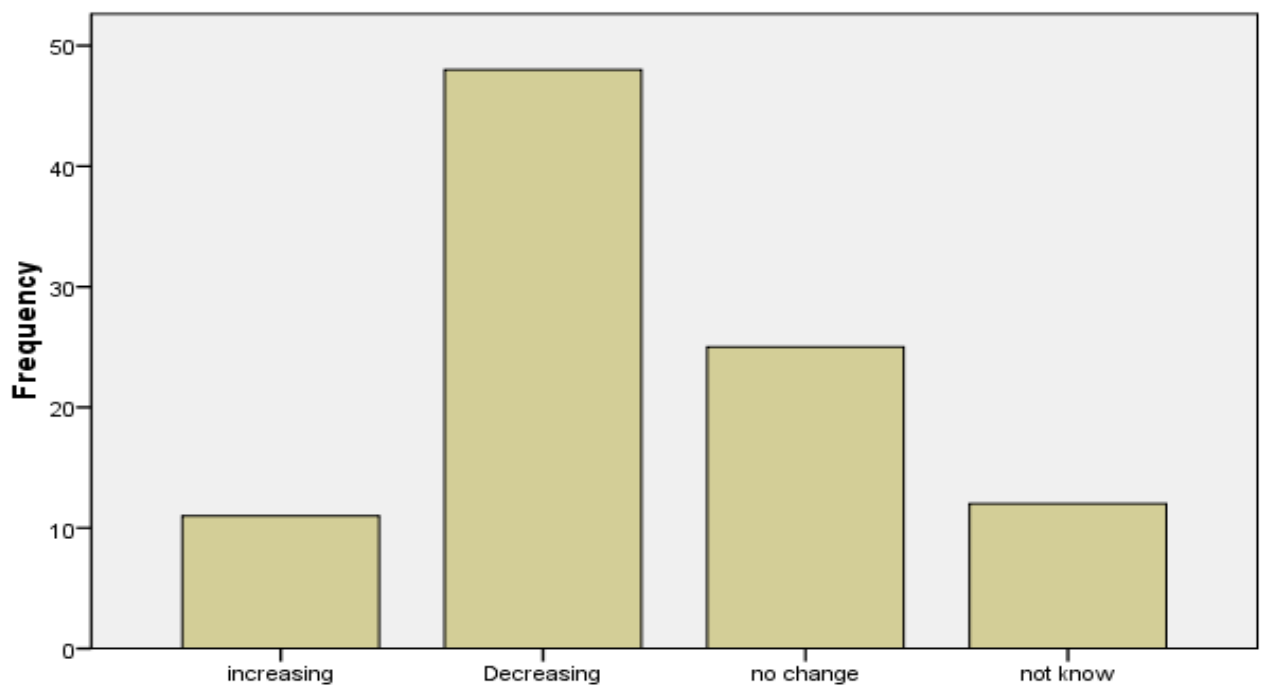

How is the consumption of the fish compared to previous decades

\begin{tabular}{|l|l|l|l|}
\hline \multicolumn{2}{|l}{ I. Table 4.16: Price cost Per Kg of Fish is } & Percent \\
\hline \multirow{3}{*}{ Valid } & $\$ 1-1.5$ & 73 & 76.0 \\
\cline { 2 - 4 } & $\$ 1.5-2$ & 23 & 24.0 \\
\cline { 2 - 4 } & Total & 96 & 100.0 \\
\hline
\end{tabular}

In Table 4.16, research respondents were asked statement of price cost per $\mathrm{kg}$ of fish is and $76 \%$ were answered that per kilo of fish is \$1-1.5, while the remaining $24 \%$ of the respondents were said the cost of per kilo of the fish is $\$$ 1.5-2. According to this research, the study found the in average cost price of kilo fish is $\$ 1.5$. in furthermore, Fish prices are determined by various factors such as quality, type and weight of fish, season, location, and the prevailing demand and supply market forces. In the domestic market (i.e. Bosaso landing beach) (A. J. Kulmiyei May 2010).

\begin{tabular}{|c|c|c|c|}
\hline \multicolumn{4}{|c|}{ J. Table 4.17 What is chain process the fish through with until reach end users } \\
\hline & & Frequency & Percent \\
\hline \multirow[t]{4}{*}{ Valid } & We keep dry Frozen & 57 & 59.4 \\
\hline & We keep Freezer with Ice & 34 & 35.4 \\
\hline & Other (Daily use only and there is no storage) & 5 & 5.2 \\
\hline & Total & 96 & 100.0 \\
\hline
\end{tabular}

According to the above table of 4.17 , the research respondents were asked the statement which was said, what is chain process the fish through with until reach end users, for this statement respondents give options and they were answered as following. 59.4\% of the respondents said we keep dry frozen, while $35.4 \%$ were agree that, they process fish through with Freezer with ice. In table 4.18, the study found that there is poor protection of fish processing in research area (Bosaso district). Also, study found that, there is financial problems faced with small firms of fish processing in area of study (Bosaso district), due that they do not have effective cold storages that they can keep fish until reach end users. Processors are private sector entities that add value to a product in a variety of 
ways; processing (changing form of a product from its original state through either mechanical/physical, chemical and/biological processes), transporting, packaging, branding, storage among other ways.

In the fisheries industry in Puntland, processing will involve cooking, drying, washing, salting, cold storage, transportation, de-gutting of fin fishes, tailing of lobsters, canning among others.

\section{CHAPTER FIVE}

SUMMARY OF FINDINGS, CONCLUSION AND RECOMMENDATIONS

\section{K. 5.1 Introduction}

This chapter gives the summary of findings, discussion, conclusions and appropriate recommendations of the study. This chapter also suggests further studies of growth on fish processing firms in Puntland.

\section{5.2 Summary of Findings}

The findings of the study have been divided into three based on the factors influencing Growth on fish processing firms in Bosaso. This study originates from the recognition that Fish production constitute one of the Economic impacts facing the future of the fish companies in Somalia. For this reason, it endeavoured to descriptive conditions for the problem conducting study in Bosaso town. For the purpose of the study, a review of the literature indicates that using the factors influencing growth on fish processing firms could be an effective indicator for understanding the magnitude of the problem and the possible areas for investigation to understand what the factors are influencing growth of the fish firms in Bosaso.

\section{5.3 culture practices}

In this variable, respondents were asked statement of according to our culture, we don't eat fish and $13.5 \%$ of the respondents answered strongly disagreed, $25.0 \%$ of the respondent replied disagreed, $59.4 \%$ of the respondents answered agree, while the remaining $2.1 \%$ responded strongly agreed. Therefore, the study found that individual are not consumes fish foods, in regarding of culture. Also, respondents were asked statement of culturally, people are more prestigiously employed in other areas nor fish industry, and $14.6 \%$ of the respondents answered disagreed, $22.9 \%$ of the respondent replied unsure, $59.4 \%$ of the respondents answered agree, while the remaining $3.1 \%$ responded strongly agreed. Therefore, the study found that the people working other areas have more prestigiously rather than of fishing sectors in culturally. Finally, in this variable, the respondents were asked statement of, for our culturally, we don't eat canned fish foods, so, in regarding of this enquire $2.1 \%$ of the respondents were answered Strongly disagree, $21.9 \%$ of the respondents were answered disagree, $2.1 \%$ of the target population answered unsure, while $70 \%$ of respondents were said agree and remaining $1 \%$ said strongly agree. So, according for the research result of above table, $71 \%$ of the people living study area agree that, we are not eating canned fish foods in regarding in our culturally. Although fish is plentiful in the waters off the Somali coast, Somalis generally do not like fish due to the traditional aspects. According the above Data analysis, this Variable have negative impact for the growth of the fish processing firms in Bosaso, since the $71 \%$ of the target population agree that, our social are not eat sea foods in regarding of the culture aspects.

\subsection{Technical Skill Availability}

According to table 4.7, the research respondents were asked the statement which said, we don't have the appropriate technically skill for fish, and $72.9 \%$ of the total respondents were answered agree, $26 \%$ were answered strongly agree while $1 \%$ were answered disagree. the study found that the small firm of fish processing in Bosaso town, they were not having appropriate technical skill for the fish. the low skills and capacities on the part of private sector actors (fishermen, processors, input providers, distributors) at all functions in to respond to and exploit present and emerging market opportunities (Amos j. Waweru, 2016). for regarding of the technical skill, the study found that, there is low monetized demand for services such as marketing, branding, market information services (MIS), cooperative management, good manufacturing/processing practices (in fish processing enterprises), business planning, negotiation and lack of awareness of a market for services on the part of potential private sector suppliers. the support study of FAO (2011), the consumption of fish is religiously and culturally acceptable and is associated with certain health benefits, but, the main reasons for low consumption are availability, cost and general lack of knowledge on storage and preparation of fish.

\section{N. 5.4 Capital Availability}

Last variable of study is influence of the capital availability on the growth of the fish processing firms, according for the research result of above table of $4.11,99 \%$ of the people living study area agree that, we don't have appropriate 
cold storage equipment for fish, and this is the biggest challenges which face the growth of the small fish firms in Bosaso, since there is not proper way they can keep fish for long time. for this result study found that, there is poor protection of fish storages. support study which said that, the cold storage and processing facilities were looted and/or destroyed, some fell into disuse and disrepair, cooperatives ceased to exist and fish markets failed (Amos j. Waweru, 2016). under this variable, the other factor of capital availability is financial problems, according to table 13 the $97.9 \%$ of the people living study area agree that, we don't have financial investment that required their business as they make growth of business, and this is the one of the challenges which face the growth of the small fish firms in the Bosaso. Somali fishermen are among the poorest and most marginalized members of Somali society. empowering them with greater knowledge about fishing and preservation methods and providing them with access to better equipment could significantly increase their standard of living and boost food security (SHURAAKO study).

\section{1) 5.4.1 Processing, ice making and cold storage facilities}

Processors are private sector entities that add value to a product in a variety of ways; processing (changing form of a product from its original state through either mechanical/physical, chemical and/biological processes), transporting, packaging, branding, storage among other ways.

In the fisheries industry in Puntland, processing will involve cooking, drying, washing, salting, cold storage and transportation.

Processing, ice making and/or cold storage facilities of one form or the other are available but it is low quality according to the major Companies along the coastline (Table 18). In total, the study was targeted 17 fish companies in Bosaso, So, these 17 companies of fish processing in Bosaso town can produced together 2.55 tons of fish/day in average. In addition to these fixed facilities, there are also over 100 of heavy duty refrigerated trucks and mobile reefer units which are mainly used in the fish cold. All the facilities are currently operational including for the NECFISH cold storage in Bosaso which was established in 1987 by the last central Government with assistance from the World Bank. This cold storage ceased operations immediately after the collapse of the Government in 1991 as it could not cover its overheads let alone make a profit without government support. However, the ice production unit continued working until 1999. The Puntland Government by way of a presidential letter rented the factory out in 2003 to a group of local businessmen who tried but failed to revive it at that time, but late was success to reopening and now is operational. The other factories of fish were totally failed to operate were Lasqoray and Habo; as study found from research respondent, a former factory manager who still oversees it, these businessmen now seek US\$300,000 from the government which they claim was spent on the factory though there is little to show for such an investment at the factory barring a $2 \mathrm{~m}$ high perimeter wall erected around the factory. Even if the dispute is resolved there is no guarantee that the factory will be revived easily since its machines have been idle for the last 20 years, gathering dust and rust.

\section{Conclusion:-}

The conclusions coming out from the findings of the research that sought to find out the factors influencing on growth of fish processing firms in Bosaso were summarized below based on the purpose of the study. The purpose of the study was to investigate factors influencing on growth of fish processing firms in Bosaso Puntland Somalia.

These factors including the influence of Capital availability, and regarding on this, it has already been demonstrated in this study the most important challenge is the poor state of the investment in Puntland specifically and in Somalia in general. Investment have only way can develop the capacity of fishing business firms, the presence of open financial markets, economic predictability, infrastructure, political stability, efficient labour markets, ability to buy required equipment and skills and human resource development.

Key priorities that need urgent attention are the physical infrastructure particularly in terms of rehabilitation of existing road network; since fish transport from far area to other Puntland regions and through with long rough roads, according to support study, (OXFAM 2016), curbing the IUU phenomenon which will include enforcement of the already existing fisheries laws, implementation of FAO recently ratified Ports Measures and improving the ability to Monitor, Control and Survey its EEZ. On its own, Puntland State does not have the capacity to undertake these reforms and enforcement measures and will therefore continue to rely on support from the international community. Any attempts to reform the investment have to be considered not as a one-off event but rather a longterm process that is participatory but also involving huge financial investments and human resources which Puntland does not have easy access due to financial constraints. 
The second factor of study was technical skill availability and according to the study analyses, the main systemic challenge here is one of skills, knowledge and attitudes of the fisheries business community. There is a general lack of awareness of the market potential of marine and fisheries products, skills in fishing, handling catch, processing (cottage and industrial), business planning and marketing. This poor level of skills, knowledge and attitude has led to very low levels of commercialization of fishing, high discards rates and by-catch and high post-harvest losses.

Last variable of this study is Culture practices and as found the study, culture is one of the factors influence growth of fish firms, because, although fish is plentiful in the waters off the Somali coast, Somalis generally do not like to eat fish because of culture. The common foods of Somalia are milk from Camel, goats and cows, since $75 \%$ of Somalia economic comes from livestock. According the above Data analysis, this Variable have negative impact for the growth of the fish processing firms in Bosaso, since the $71 \%$ of the target population agree that, our social are not usually eat sea foods in regarding of the culture aspects.

\section{Recommendations:-}

The recommendations of this study are based on the conclusions of the challenges identified by the respondents who participated in the study. To address the problem of growth on fish processing firms in Bosaso town, the study recommends the following:

In base of the findings of this study recommend that, the Puntland Government to support construction of Cold rooms and fish processing centres. Also, recommended the Small firms can make together one corporation which can enable to cover financial capacity required business fish companies.

To enhancing the skill of the staff working with the fish firms, recommend to make staff capacity building as to upgrade their technical skills and knowledge and also, providing training to improving fish handling, Marketing and processing to stakeholder of fish market.

Taking awareness and mobilization on adverse impact of fish consumption benefits and how can contribute the economic developments.

\subsection{Suggestions for further research}

From the findings of this research, the researcher recommends follow up studies on the following topics:

1. Study should be done the evaluation for the role of fish production in Puntland Economic.

2. Study should be done on the other factors that influence the fish growth including consumption and marketing.

3. Same study can be conducted on another area to compare the findings

\section{References:-}

1. Egziabher, G. (2016). IGAD Regional Fisheries and Aquaculture Draft Strategy. Addis Ababa: IGAD.

2. FAO. (2005). National Development and poverty reduction strategies. FAO. China

3. Fellner, A. (2008). Role of Culture in Economic Development in China . China.

4. FSNAU. (2011). Somali Knowledge Attitude \& Practices Study in Fish Consumption. FAO.

5. German. B., \&. G. (2015). Talent, Labor Quality, and Economic Development. ELSEVIER.

6. Kluckhohm, K. A. (2016). Report on proposed Puntland fisheries value chain upgrading strategy. Puntland.

7. Kimathi Antoney Njagi, I. C. (2013). Factors Affecting Profitability of Fish Farming Under Economic Stimulus Programme in Tigania East District, Meru County. IOSR Journal of Business and Management (IOSR-JBM).

8. Kulmiye, A. J. (2010). Assessment of the status of the artisanal fisheries in Puntland through value chain analysis. VSF SUISSE.

9. Lewis, W. A. (1950). The Lewis Theory of Development. Economic Development Book.

10. Michael Savins. (2016). Fisheries infrastructure and fleet renewal Unit in Bosaso. Bosaso: FAO.

11. Mumin, F. A. (2017). Factors affecting growth of the fishing industry in Puntland. Garowe: IJAR.

12. Nguyen_Thanh_Cuong. (2014). Threshold Effect of Capital Structure on Firm. Vietnam: Juornal.

13. Ricardo, D. (1917). Labour process theory. Oxford. USA.

14. Ridler and Hishamunda. (2001). Family Business with traditional techniques passed from generation to generation. China .

15. Sen. A. (1997). The values held by a society will affect economic development efforts . USA.

16. Spivak, K. H. (2015). Study of the Fishing Sector in Somalia/Somaliland. Shuraako.

17. Waweru, A. J. (2016). Report on Proposed Puntland fisheries Value chain strategy. OXFAM. 
18. Weimin, J. (2007). Freshwater aquaculture in China . China.

19. Xuewen, L. (1997). Chinese scholars claim, politics, economics and culture are the three gears of any society. Chinese.

\section{APPENDIX}

O. Fishing Data Collection Questionnaire

AssalamuAleykum., My name is Abdihakiim Abdullahi Nuh, a student of Masters of Development Studies at Jomo Kenyatta University of Agriculture and Technology. I am conducting my research project on factors influence growth of fish processing firms in Bossaso. The information you provide will remain confidential, add value and diversity to this study and shall not be used under circumstance to inflict harm you physically or your personality. I am going to ask you a few questions which you will reply. Please be sincere with your answers and feel free to not answer any questions you feel inappropriate or even to withdraw from the interview if you wish. If it is ok, I would like to start the interview now.

Part One: General Information.

Please tick $(\sqrt{ })$ in the bracket in front of the most appropriate response and where explanation is required, use the space provided.

\section{Gender: 1. Male ( )}

2. Female ( )

2. Age: $1.20-25$ ( )
2. $26-30()$
3. $31-35()$
4. $36-40()$
5. 41-45
6. 46 and +()

3. Marital status: 1. Married ( )
2. Single ( )
3. Widow ( )
4. Divorced ( )

4. Education level: 1. Primary level
2. Secondary Level ( )
3. Bachelor's degree ( )
4. Master's Degree ( )
5. Any other (specify)

\section{Part two: Culture Practices}

Using liker scale elaborated below factors influence growth of fish processing firms in Bossaso,Puntland, kindly respond your answer of each question by selecting the following options:

5= Strongly Agree (SA),

4= Agree (A),

$3=$ Unsure (U),

$2=$ Disagree $(\mathrm{D})$, and

1= Strongly Disagree (SD).

\begin{tabular}{|l|l|l|l|l|l|}
\hline Culture Practices & 5 & 4 & 3 & 2 & 1 \\
\hline Statements & & & & & \\
\hline According to our culture, we don't eat fish & & & & \\
\hline $\begin{array}{l}\text { Culturally, people are more Prestigiously employed in other areas nor } \\
\text { fishing industry }\end{array}$ & & & & \\
\hline For our culture, we don't eat canned fish foods & & & & \\
\hline
\end{tabular}


Part three: Technical Skills

\begin{tabular}{|c|c|c|c|c|c|}
\hline \multicolumn{2}{|l|}{ Technical Skills } & & & & \\
\hline Statements & 5 & 4 & 3 & 2 & 1 \\
\hline We don't have appropriate technically for fishi & & & & & \\
\hline We don't know how to add value to fish & & & & & \\
\hline We don't have appropriate fish customer care & & & & & \\
\hline
\end{tabular}

PART FOUR: CAPITAL AVAILABILITY

\begin{tabular}{|l|l|l|l|l|l|}
\hline Capital Availability & \multicolumn{1}{|l|}{$\mid$} \\
\hline Statements & 5 & 4 & 3 & 2 & 1 \\
\hline We don't have appropriate cold storage for fish. & & & & & \\
\hline We don't have land capital required our business & & & & & \\
\hline $\begin{array}{l}\text { We don't have financial investment our business } \\
\text { required }\end{array}$ & & & & & \\
\hline
\end{tabular}

PART FIVE:DEPENDENT VARIABLE

1. How many years have been working your Company in Business of fishing sector?
a. 0-2 years
b. 2-4 years
c. 4-6 years
d. 6-12 years

2. In Average, how much fish your company produce per month
a. $50-100 \mathrm{Kgs}$
b. $100-150 \mathrm{Kgs}$
c. $150-200 \mathrm{Kgs}$
d. $200-250 \mathrm{Kgs}$
e. $250-300 \mathrm{Kgs}$
f. $300 \mathrm{Kgs}$ or more than

3. How is the consumption of the fish compared to previous decades?
a. Increasing
b. Decreasing
c. No change
d. Not know
e. Other (specify)

4. The Price cost per $\mathrm{Kg}$ of fish is?
a. $\$ 1-1.5$
b. $\$ 1.5-2$
c. $\$ 2.5-3$
d. More than \$3

5. What is chain process the fish through with until reach end user. Please give explanation the below space?

6. What are the main constraints to fishing activities currently? 
7. How do you think fishing activities can be improved considering production and marketing issues? 